\title{
KINETIKA PROSES AOPS UNTUK PENGHILANGAN WARNA AIR LIMBAH PRODUKSI BATIK
}

\author{
Oleh : \\ Rudi Nugroho dan Ikbal \\ Peneliti pada Pusat Pengkajian dan Penerapan Teknologi Lingkungan BPPT
}

\begin{abstract}
An experiment of Advanced Oxydation Processes (AOPs) was conducted in semi-pilot scale using ozon and hydrogen peroxide. The reaction of ozon and hydrogen peroxide produce an active hydroxil which can crack a long-chain organic compounds such as azo dyes. A wastewater contains colour substances coming from batik industries in Jababeka was treated by AOPs. The reaction rate was affected by ozon concentration supplied to the wastewater. The more ozon concentration, the colour removal became faster. The colour removal using AOPs could be illustrated by first-order chemical reaction equation. The constant of reaction was calculated from experiment as high as 0,38 per hour. The cost for treating the wastewater using AOPs was Rp.3.656,- for one cubic meter of wastewater.
\end{abstract}

Key words: AOPs, Colour Removal, Hydrogen Peroxide, Ozon,

\section{PENDAHULUAN}

Masalah warna pada air limbah industri saat ini menjadi perhatian serius dalam menentukan teknologi pengolahan air limbah. Penghilangan warna bahkan terkadang menjadi masalah yang lebih penting dibandingkan polutan-polutan lain seperti BOD dan COD. Hal ini karena limbah yang keluar dari suatu industri apabila mengandung warna yang pekat, secara psikologis akan membawa persepsi ke masyarakat awam bahwa limbah tersebut sangat berbahaya walaupun kadar polutan organik yang terkandung dalam air limbah tersebut berada dibawah baku mutu yang ditetapkan oleh pemerintah.

Peraturan baku mutu air limbah kegiatan industri baik itu untuk nasional yang diterbitkan oleh Menteri Negara Lingkungan Hidup maupun peraturan regional yang diterbitkan oleh Perda, tidak ada satupun yang membatasi warna air limbah. Inisiatif industri-industri dalam mereduksi warna air limbah yang dibuangnya itu hanya semata-mata tekanan dari masyarakat yang tinggal di sekelilingnya. Karenanya masih sangat banyak air limbah yang keluar dari suatu industri yang masih mengandung warna cukup pekat.

Proses pengolahan air limbah konvensional seperti lumpur aktif, biofilter anaerob-aerob secara teknis tidak akan efektif untuk mengatasi masalah warna dalam air limbah. Selain itu juga proses biologis tidak ekonomis untuk mendegradasi zat warna dari jenis organik rantai panjang. Organik rantai panjang seperti azo dyes untuk pewarna tekstil, merupakan senyawa organik yang sangat sulit di uraikan/didegradasi dengan proses biologis. Untuk dapat mencapai efisiensi penurunan warna yang signifikan pada air limbah dengan proses biologis, diperlukan waktu tinggal yang sangat lama. Hal ini akan membawa dampak kepada dimensi reaktor pengolah air limbah yang besar yang pada akhirnya menimbulkan biaya investasi yang tinggi.

Menurut teori, teknologi penghilangan warna yang paling banyak dipakai adalah dengan oksidasi kimia yang selanjutnya apabila diperlukan, air olahan proses kimia diproses lebih lanjut dengan proses biolgis. Studi pertama kali dilakukan dengan menggunakan klorin dan potassium permanganate. Pada kasus menggunakan klorin sebagai oksidator, timbul efek negatif yaitu terbentuknya senyawa dioksin penyebab kangker (carcinogen). Dioksin ini muncul sebagai akibat dari hasil reaksi antara khlorine dengan senyawa organik tertentu.

Menurut Brian dan Hamouda, teknologiteknologi penghilangan warna pada air limbah pencucian dapat dilakukan dengan proses batch menggunakan teknologi-teknologi sebagai berikut:
1) Filtrasi dengan membrane
2) Adsorbsi dengan karbon aktif
3) Penukar ion
4) Ultra violet dan Hidrogen Peroksida
5) Ozon

Filtrasi dengan membrane pertama-tama diuji coba untuk menghilangkan warna dari air limbah pencucian tersebut. Namun hasilnya warna tidak dapat turun secara signifikan.

Uji coba kedua dilakukan dengan menggunakan karbon aktif untuk menyerap warna. Pada percobaan ini dapat diketahui kemampuan karbon aktif yang sangat baik dalam 
menyerap warna dari berbagai jenis zat warna. Dosis minimum yang diperlukan untuk mengilangkan warna dalam air limbah dapat diketahui sebesar $105 \mathrm{~g}$ karbon aktif untuk setiap liter air limbah. Namun demikian biaya untuk proses penurunan warna dengan karbon aktif cukup besar yaitu sekitar 0,12 US $\$$ untuk biaya proses, dan 1,1 US\$ per $\mathrm{kg}$ karbon aktif. Teknologi lain penghilangan warna yaitu penukar ion, dicoba dengan menggunakan resin komersial, dan hasilnya menunjukkan kalau warna dapat terserap dengan baik. Namun sayangnya reaksi resin dalam menyerap zat warna bukanlah reaksi reversible, sehingga tidak memungkinkan untuk dilakukannya regenerasi resin. Dengan tidak dapat diregenarasinya resin, maka akan membawa dampak kepada biaya untuk kebutuhan resin yang mahal dan selain itu juga menimbulkan polusi sekunder dari resin yang tidak dapat digukanan. Oleh karena itu teknologi ini sekarang sudah mulai ditinggalkan.

Cara lain penghilangan warna yang dicoba oleh Brian dan Hamouda adalah dengan menggunakan larutan Hidrogen peroksida yang disinari dengan sinar Ultra Violet. Tujuan penyinaran dengan ultra violet adalah untuk mengaktifkan hydrogen peroksida sehingga dapat membentuk radikal bebas. Hidrogen peroksida yang digunakan sampai konsentrasi $30 \%$. Walaupun dosis penambahan hydrogen peroksida sudah cukup banyak, namun hanya sedikit warna dapat berkurang dan untuk warnawarna yang pekat, teknologi ini tidak dapat diaplikasikan.

Cara penghilangan warna pada air limbah pencucian juga dilakukan dengan ozon dalam skala laboratorium dengan menggunakan ozon generator. Ozon dikontakkan dengan air limbah melalui diffuser yang terbuat dari batuan yang berpori-pori. Efisiensi kontak antara ozon dengan air limbah dapat mencapai 54\%. Ozon diproduksi dari udara dengan ozon generator kapasitas $6 \mathrm{~g}$ per jam. Dari perhitungan diperlukan ozon sebanyak $0,12 \mathrm{~kg}$ ozon untuk setiap liter air limbah warna.

Teknologi pengolahan air limbah berwarna skala industri pertama kali diterapkan di Nagahama Plants Jepang tahun 1974. Teknologi ini menggunakan sistem kombinasi karbon aktif dan ozon yang dikenal dengan nama GAC. Air limbah berwarna disuplai kedalam tangki bentuk kolom dengan volume $600 \mathrm{~m} 3$. Tangki tersebut diisi dengan karbon aktif granular. Jumlah ozon yang disupai kedalam tangki adalah sebesar 7,2 $\mathrm{kg} / \mathrm{jam}$. Hasilnya menunjukkan kalau warna dapat teroksidasi dan turun kepekatannya. Sedangkan COD dan BOD5 dapat turun 60 $80 \%$. Karena efektifitas ozon dalam menurunkan warna, di Jepang saat ini sudah banyak yang menerapkannya dan kapasitas terbesar saat ini mencapai $12.000 \mathrm{~m} 3$ limbah tekstil per hari.

$\mathrm{Di}$ Indonesia, penelitian pengolahan air limbah berwarna telah dilakukan oleh Rudi dan Ikbal untuk mengolah air limbah berwarna produksi batik dengan menggunakan ozon dicampur hidrogen peroksida (AOPs). Penelitian ini dilakukan pada skala laboratorium dengan menggunakan Erlenmeyer 2 liter. Seperti pada reaksi hidrogen peroksida dengan sinar ultra violet, reaksi ozon dengan hidrogen peroksida ditujukan untuk pembentukan radikal aktif hidroksil. Radikal aktif hidroksil ini yang berperan memecah organik rantai panjang zat warna menjadi organik dengan rantai yang lebih pendek yang bersifat lebih degradable. Reaksi peruraian warna dengan radikal hidroksil berlangsung sebagai berikut:

$$
\mathrm{H}_{2} \mathrm{O}_{2}+2 \mathrm{O}_{3}-->\mathrm{HO}^{*}+\mathrm{HO}^{*} \text { (radikal aktif) }+3 \mathrm{O}_{2}
$$

Kesimpulan dari penelitian ini adalah diantaranya semakin tinggi konsentrasi ozon yang digunakan, maka reaksi pengilangan warna dengan AOPs akan semakin cepat. Suhu optimum pada proses AOPs adalah $70^{\circ} \mathrm{C}$. Kondisi ini sangat menguntungkan karena kebanyakan air limbah yang keluar dari industri bersuhu diatas suhu kamar. Reaksi AOPs akan berjalan cepat pada suasana basa, yaitu $\mathrm{pH}$ 12.Penambahan hidrogen peroksida $0,25 \mathrm{ml}$ untuk setiap 1 liter air limbah dapat mempercepat proses reaksi AOPs. Namun demikian pada penelitian ini masih berskala kecil sehingga data-data yang dihasilkan masih bersifat data dasar yang belum memungkinkan untuk diaplikasikan pada skala Industri.

Pada tulisan ini dibahas lebih lanjut mengenai penelitian AOPs dengan skala lebih besar yaitu menggunakan peralatan semi pilot skala 100 liter. Tujuan dari penelitian ini adalah untuk merumuskan parameter kinetika yang dapat dipakai sebagai dasar untuk mendisain alat skala industri.

\section{KINETIKA REAKSI PENGHILANGAN WARNA}

Reaksi penghilangan warna pada air limbah dengan proses AOPs dapat dikategorikan sebagai reaksi kimia. Dengan demikian suhu, keasaman dan juga jumlah reaktan atau konsentrasi dapat berpengaruh pada kecepatan reaksi. Secara umum kecepatan reaksi kimia dapat dirumuskan sebagai berikut:

$$
-r_{A}=k C_{A}^{n}
$$

Dimana : -ra : kecepatan reaksi

$\mathrm{k}$ : konstanta kecepatan reaksi 


$$
\begin{aligned}
& C_{\mathrm{A}} \text { : konsentrasi reaktan } \\
& \mathrm{n}: \text { orde reaksi }
\end{aligned}
$$

Dengan mengaplikasikan persamaan (1) diatas untuk merumuskan kecepatan penurunan warna pada reaksi dengan AOPs maka konsentrasi reaktan $C_{\mathrm{A}}$ dinyatakan dengan angka konsentrasi warna PtCo. Nilai orde reaksi $n$ dapat dihitung dari data hasil percobaan dengan menggunakan persamaan sebagai berikut: (Octav dan Levenspiel, 1972)

$$
n=1-\frac{\log t_{1}-\log t_{2}}{\log C\left(A_{1}\right) o-\log C\left(A_{2}\right) o}
$$

dimana $t_{1}$ menunjukkan waktu ketika konsentrasi mencapai $1 / 2$ dari konsentrasi awal percobaan $1, C\left(A_{1}\right)$ menunjukkan setengah dari konsentrasi awal percobaan 1, t2 menunjukkan waktu ketika konsentrasi mencapai $1 / 2$ dari konsentrasi awal pada percobaan $2, C\left(A_{2}\right)$ menunjukkan setengah dari konsentrasi awal percobaan 2.

Untuk nilai $\mathrm{n}=0$ maka rumus kecepatan reaksi penurunan warna akan menjadi seperti berikut:

$$
\begin{aligned}
& -r_{A}=k C_{A}{ }^{0} \\
& =\frac{d C_{A}}{d t}=-k \\
& =C_{A 0}-C_{A}=k t
\end{aligned}
$$

Untuk $\mathrm{n}=2$

$$
\begin{aligned}
& -r_{A}=k C_{A}^{2} \\
& =\frac{d C_{A}}{d t}=-k\left(C_{A}\right)^{2} \\
& =\frac{1}{C_{A}}-\frac{1}{C_{A 0}}=k t
\end{aligned}
$$

Dimana : $-r_{A}:$ kecepatan reaksi.

$\mathrm{k}$ : konstanta kecepatan reaksi penurunan warna.

$C_{\mathrm{A}}$ : konsentrasi warna reaktan.

$\mathrm{t}$ : waktu reaksi.

\section{PROSEDUR UJI COBA PENGOLAHAN LIMBAH WARNA}

\subsection{Air limbah}

Air limbah yang digunakan untuk uji coba diambilkan dari unit pre-treatment proses produksi batik di pengolahan air limbah terpadu PT. Jababeka Infrastruktur. Air limbah ini mengandung COD dan konsentrasi warna yang berfariasi tergantung dari waktu pengambilan. Konsentrasi COD tertinggi sekitar $950 \mathrm{mg} / \mathrm{l}$ dan terendah $350 \mathrm{mg} / \mathrm{l}$. Konsentrasi warna tertinggi sekitar 5640 PtCo dan terendah sekitar 2390 PtCo. Sedangkan $\mathrm{pH}$ air limbah berkisar antara 7 - 8,5. Data-data mengenai air limbah yang diuji coba telah dipaparkan oleh Rudi dan Ikbal pada tulisan sebelumnya. Untuk uji coba konsentrasi warna air limbah rendah, air limbah asli diencerkan dengan air sampai mencapai tingkat warna yang diinginkan.

\subsection{Peralatan Uji Coba}

Uji coba pengolahan air limbah berwarna dengan proses AOPs dilakukan secara batch pada skala semi pilot dengan menggunakan prototipe alat kapasitas 100 liter. Skema prototipe alat seperti terlihat pada Gambar 2.

Prototipe alat terdiri dari sumber gas pembuat ozon dalam bentuk kompresor udara atau tabung gas oksigen murni, pengering gas, ozon generator merek ozotech, flow meter dari stainless steel, tabung akrilik sebagai kontaktor ozon, pompa sirkulasi dan sistem perpipaan yang dilengkapi venturi (Gambar 3).

Proses uji coba pengolahan limbah berwarna dilakukan dengan prosedur sebagai berikut :

Pertama air limbah dimasukkan ke dalam kontaktor ozon sebanyak 100 liter. Kemudian ozon generator dihidupkan dan dibiarkan selama 30 menit untuk pemanasan. Setelah 30 menit, hidrogen peroksida ditambahkan ke dalam air limbah sebanyak 0,25 $\mathrm{ml}$ untuk setiap 1 liter air limbah. Hidrogen peroksida yang ditambahkan adalah hidrogen peroksida teknis dengan kadar $70 \%$. Selanjutnya kompresor udara dihidupkan dan udara dialirkan ke dalam generator ozon untuk selanjutnya ozon yang terbentuk mengalir ke kontaktor ozon melalui flow meter dan difuser untuk bereaksi dengan air limbah. Sisa ozon yang tidak bereaksi disedot dengan tenaga yang dihasilkan dari sirkulasi air limbah melalui venturi, untuk direaksikan kembali dengan air limbah dalam kontaktor ozon. Dengan demikian, udara yang keluar dari kontaktor ozon sudah tidak lagi mengandung ozon. 


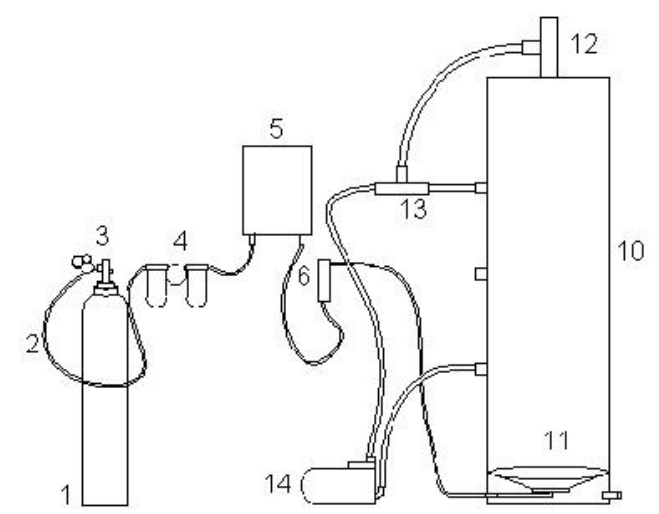

Keterangan :
1. Sumber gas (tabung gas)
2. Selang penghubung
3. Regulator flow
4. Filter udara
5. Pembangkit Ozon

\subsection{Parameter Yang Diuji}

Pada uji coba dengan prototipe alat pengolah air limbah berwarna proses AOPs ini dilakukan pada berbagai kondisi percobaan seperti konsentrasi ozon yang digunakan, laju alir gas/ozon dan juga konsentrasi awal warna air limbah. Untuk semua uji coba, hidrogen peroksida yang ditambahkan tetap yaitu $0,25 \mathrm{ml}$ untuk setiap 1 liter air limbah. Laju alir ozon divariasi 1, 3 dan 5 liter per menit dan kapasitas ozon dibuat 0,56 dan 1,2 g per jam. Untuk masing masing kondisi uji coba, diamati perubahan warna dan COD setiap periode tertentu.

\section{HASIL UJI COBA DAN PEMBAHASAN}

\subsection{Penurunan Konsentrasi Warna dan COD}

Gambar 4 menunjukan penurunan konsentrasi warna pada proses AOPs skala semi pilot. Pada saat sumber gas pembuat ozon menggunakan udara yang dihembus dari kompresor yaitu kondisi percobaan 0 sampai 3 jam, penurunan konsentrasi warna terlihat lambat. Namun pada saat sumber gas pembuat ozon diganti dengan oksigen murni yaitu setelah jam ke 3 sampai akhir uji coba, penurunan konsentrasi warna terhadap waktu pada proses AOPs terlihat semakin cepat yaitu dari konsentrasi 2450 PtCo turun sampai sekitar 1260 PtCo.

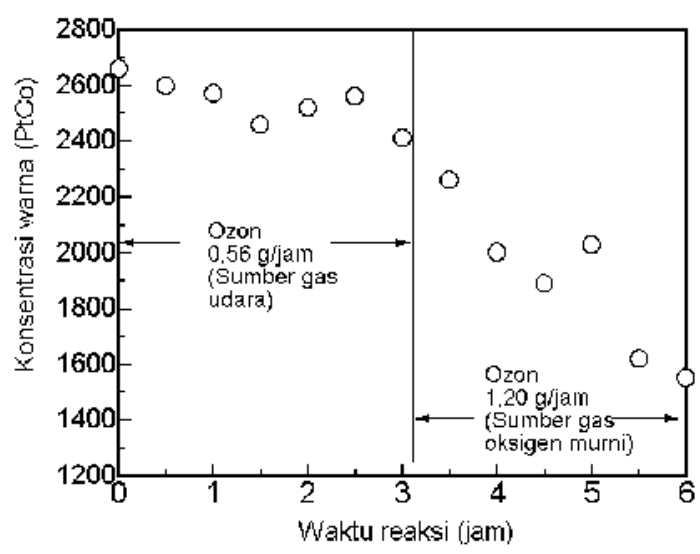

Gambar 4 : Penurunan warna pada proses AOPs dengan konsentrasi ozon $0,56 \mathrm{~g} / \mathrm{jam}$ dan $1,2 \mathrm{~g} / \mathrm{jam}$, laju alir gas 1 liter per menit.

Pada proses AOPs dimana sumber gas menggunakan oksigen murni, pada spesifikasi ozon generator type ozotech tertulis dapat menghasilkan gas ozon dengan jumlah dua kali lipat dari jumlah ozon yang dihasilkan dibanding apabila menggunakan sumber gas udara. Dengan sumber gas udara ozon yang dapat 
dibangkitkan sebesar 0,56 g/jam, dan dengan sumber gas oksigen murni ozon yang dapat dibangkitkan sebesar 1,2 g/jam. Dari gambar 4, kecepatan penurunan warna dapat dihitung sekitar 100 PtCo per jam dengan ozon 0,56 g per jam dan 300 PtCo per jam dengan ozon sebesar 1,2 g per jam atau naik kecepatannya tiga kali lipat. Dengan demikian dapat ditarik kesimpulan bahwa apabila ozon yang digunakan untuk proses AOPs diperbesar kapasitasnya dua kali lipat, maka kecepatan penurunan warna akan bertambah tiga kali lipat. Ini mungkin disebabkan karena jumlah hidrogen peroksida yang membentuk radikan aktif $\mathrm{OH}$ bertambah banyak secara signifikan apabila jumlah ozon besar.

Gambar 5 menunjukkan penurunan warna dan COD dengan sumber gas oksigen murni dan laju alir gas 1 liter per menit. Hampir sama dengan hasil pada gambar 4 , warna turun dari 2500 PtCo menjadi sekitar 1200 PtCo dalam waktu 5 jam. Namun penurunan COD terlihat tidak signifikan yaitu turun dari $380 \mathrm{mg} / \mathrm{l}$ menjadi $260 \mathrm{mg} / \mathrm{l}$. Penurunan COD bukanlah tujuan utama proses AOPs. Yang lebih penting adalah putusnya ikatan kimia rantai panjang menjadi rantai yang lebih pendek. Turunnya konsentrasi warna setelah proses AOPs disini menunjukkan bahwa ikatan kimia rantai panjang yang menimbulkan sifat berwarna sudah mengalami perubahan atau putus menjadi rantai yang lebih pendek. Sayangnya, nama senyawa kimia zat pewarna yang digunakan untuk pewarnaan di industri batik merupakan rahasia perusahaan sehingga penulis tidak dapat memaparkan bagaimana mekanisma reaksi penghilangan warna yang sebenarnya. Namun demikian dapat diilustrasikan sebagai berikut:

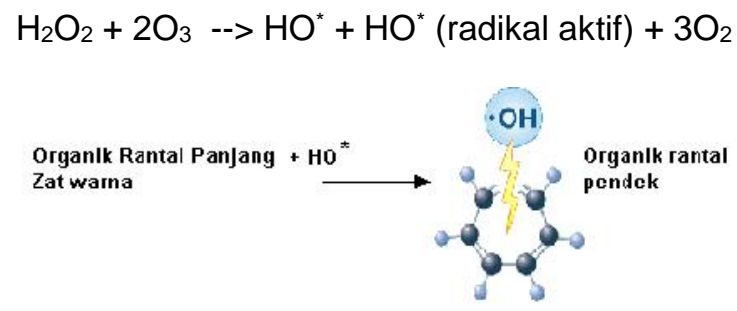

Dengan putusnya rantai kimia panjang menjadi rantai yang lebih pendek, maka sifat warna dan sifat racun akan dapat berkurang. Selain itu pula senyawa organik rantai pendek cenderung lebih mudah terurai oleh mikroba. Dengan demikian senyawa organik hasil dari proses AOPs dapat di proses lebih lanjut dengan teknologi pengolahan limbah sistem biologis konvensional seperti halnya lumpur aktif atau biofilter anaerob-aerob sampai angka COD turun memenuhi baku mutu air limbah untuk dapat dibuang ke perairan. Sebenarnya dengan AOPs pun, apabila waktu reaksinya diperlama $C O D$ dapat turun. Namun dengan pertimbangan ekonomis maka proses AOPs hanya dikhususkan untuk memutus ikatan kimia sampai dengan tingkat dapat terurai secara biologis.

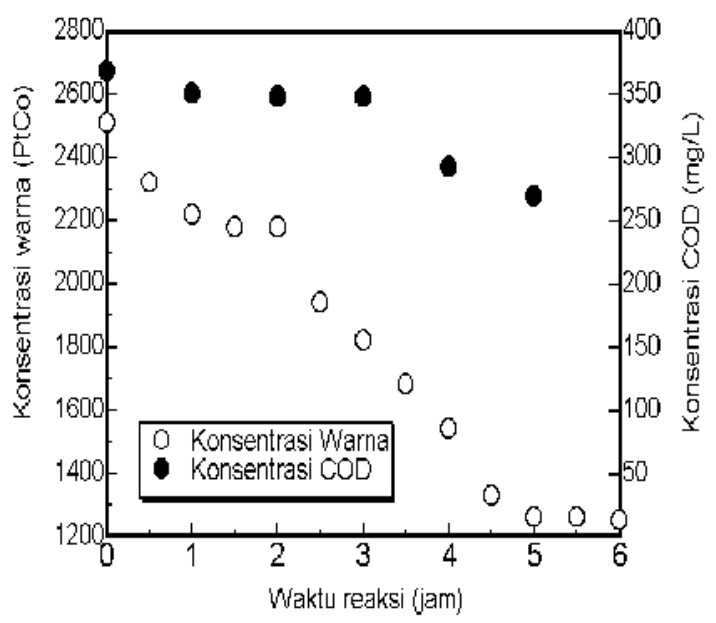

Gambar 5 : Penurunan warna dan COD pada proses AOPs skala semi pilot dengan konsentrasi Ozon 1,2 g per jam dan laju alir gas 1 liter per menit.

\subsection{Pengaruh Laju Alir Gas}

Gambar 6 menunjukkan pengaruh laju alir gas terhadap penurunan warna pada proses AOPs. Selama 5 jam proses AOPs berlangsung, warna turun dari sekitar 5700 PtCo menjadi sekitar $4200 \mathrm{Pt}$ Co untuk laju alir gas 1 dan 5 liter per menit. Penurunan warna yang lebih besar terjadi pada laju alir gas 3 liter per menit yaitu turun dari 5700 PtCo menjadi sekitar 3200 PtCo.

Gas, dalam hal ini oksigen murni atau oksigen dalam campuran udara dipakai sebagai bahan baku pembangkit ozon. Pada proses pembangkitan ozon, gas ini akan melewati dua lempengan tegangan tinggi sehingga akan terbentuk ozon. Dengan demikian, kecepatan alir yang terlalu tinggi akan mengurangi efisiensi pembentukan ozon dalam ozon generator karena waktu tinggal gas dalam lempengan tegangan tinggi sangat singkat. Pada kondisi dimana gas berada terlalu lama diantara lempengan tegangan tinggi, ozon yang terbentuk jumlahnya banyak. Namun karena pengaruh panas dari lempengan tegangan tinggi, ozon terbentuk akan mengalami dekomposisi kembali sehingga total jumlah ozon yang dibangkitkan menjadi kecil. Oleh karena itu ada kecepatan alir gas optimum dimana ozon yang dibangkitkan maksimum. Diantara laju alir gas 1 sampai dengan 5 liter per menit, di simpulkan laju alir optimum berada di kisaran 3 liter per menit. Dengan demikian, untuk percobaan-percobaan selanjutnya dilakukan dengan kondisi laju alir gas 3 liter per menit. 


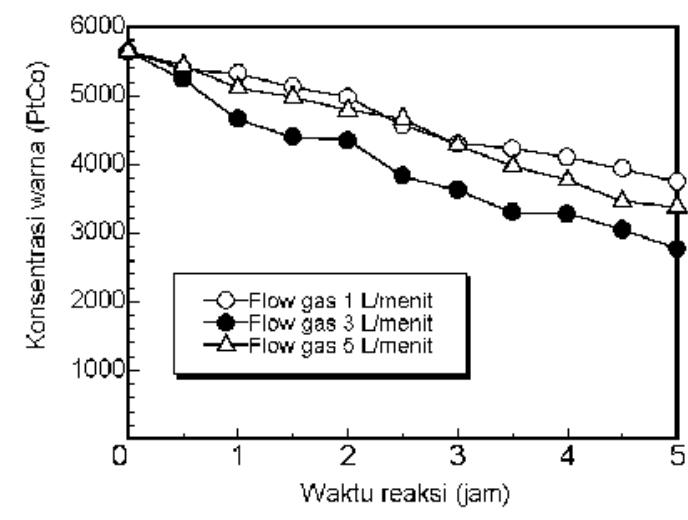

Gambar 6 : Pengaruh laju alir gas terhadap penurunan warna pada proses AOPs

\subsection{Percobaan Mencari Orde Reaksi AOPs}

Reaksi penurunan warna dengan proses AOPs merupakan reaksi kimia dan dapat di rumuskan dengan persamaan 1 dan 2 diatas. Untuk mencari nilai orde reaksi $\mathrm{n}$, dilakukan dengan percobaan pada kondisi konsentrasi awal warna yang berbeda yaitu 1570 PtCo dan 1100 PtCo.

Gambar 7 menunjukkan hasil percobaan. Dari gambar terlihat kalau konsentrasi warna yang lebih tinggi akan menghasilkan kecepatan penurunan warna lebih cepat dibandingkan dengan konsentrasi warna yang lebih rendah. Hal ini merupakan kecenderungan reaksi kimia dengan orde diatas 0 . Dari gambar juga dapat diketahui kalau waktu untuk dapat mencapai konsentrasi warna menjadi $1 / 2$ dari konsentrasi awal yaitu menjadi 780 dan 550 PtCo adalah 2,5 jam untuk kedua kondisi percobaan. Dengan memasukkan angka-angka ini kedalam persamaan 2 , maka diperoleh nilai orde reaksi $n$ $=1$

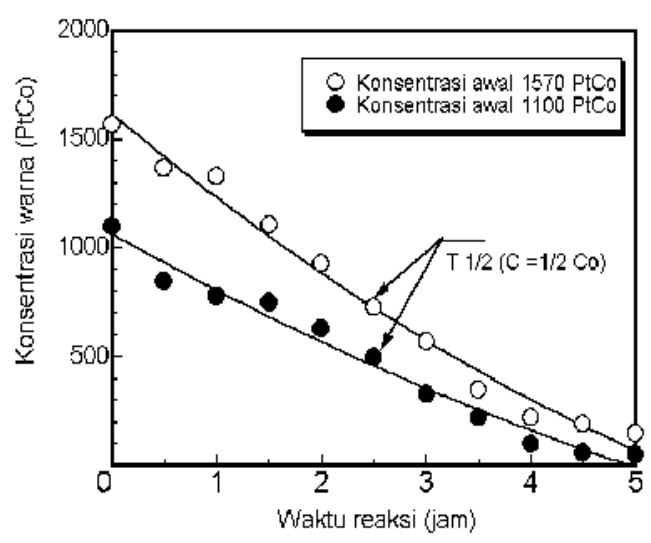

Gambar 7 : Penurunan warna pada proses AOPs dengan konsentrasi awal 1570 dan $1100 \mathrm{PtCo}$, konsentrasi ozon 1,2 g/jam, laju alir gas 3 liter per menit.

\subsection{Percobaan Mencari Konstanta}

\section{Kecepatan Reaksi AOPs}

Selain orde reaksi, konstanta kecepatan reaksi $\mathrm{k}$ merupakan parameter penting yang berguna untuk mendisain reaktor AOPs. Apabila telah diketahui nilai $\mathrm{k}$ dan $\mathrm{n}$, maka dapat dihitung waktu tinggal air limbah dalam reaktor AOPs, dimensi reaktor dan efisiensi penurunan warna yang dapat dicapai.

Percobaan untuk mencari nilai konstanta $\mathrm{k}$ dilakukan pada 3 tingkat konsentrasi warna awal air limbah. Data penurunan warna percobaan ini dapat dilihat pada Tabel 1. Nilai $k$ dihitung untuk kecepatan reaksi pada 2 jam pertama yaitu dengan membagi perbedaan konsentrasi warna pada saat 0 jam dan 2 jam dibagi dengan waktu. Hasil perhitungan nilai $\mathrm{k}$ dapat dilihat pada Tabel 2.

Tabel 1 : Data percobaan mencari nilai k.

\begin{tabular}{|c|c|c|c|}
\hline \multirow{2}{*}{$\begin{array}{c}\text { Waktu } \\
\text { reaksi } \\
\text { (jam) }\end{array}$} & \multicolumn{3}{|c|}{ Konsentrasi warna (PtCo) } \\
\hline 0 & $\begin{array}{c}\text { Percobaan } \\
\text { I }\end{array}$ & $\begin{array}{c}\text { Percobaan } \\
\text { II }\end{array}$ & $\begin{array}{c}\text { Percobaan } \\
\text { III }\end{array}$ \\
\hline 0,5 & 1100 & 1240 & 1570 \\
\hline 1,0 & 850 & 1180 & 1370 \\
\hline 1,5 & 780 & 980 & 1330 \\
\hline 2,0 & 630 & 880 & 1110 \\
\hline 2,5 & 500 & 840 & 930 \\
\hline 3,0 & 330 & 610 & 730 \\
\hline 3,5 & 220 & 530 & 570 \\
\hline 4,0 & 100 & 500 & 350 \\
\hline 4,5 & 60 & 470 & 220 \\
\hline 5,0 & 50 & 460 & 190 \\
\hline
\end{tabular}

Tabel 2 : Hasil perhitungan nilai k (satuan: jam-1)

\begin{tabular}{|c|c|c|c|}
\hline \multicolumn{3}{|c|}{ Nilai k } & k rata-rata \\
\hline Perc. 1 & Perc. 2 & Perc.3 & \\
\hline 0,42 & 0,32 & 0,40 & 0,38 \\
\hline
\end{tabular}

\subsection{Analisa Ekonomi Proses AOPs}

Analisis biaya proses AOPs dihitung dengan menggunakan asumsi proses AOPs digunakan untuk menurunkan warna dari 2500 PtCo sampai menjadi 500PtCo. Dari persamaan 4 didapatkan kalau waktu tinggal air limbah di kontaktor ozon sekitar 4,2 jam. Untuk volume reaktor 100 liter dan dilakukan proses kontinyu, maka debit air limbah per jamnya sekitar 23,6 liter. Daya ozon generator yang digunakan sebesar 100 watt. Harga listrik di jakarta untuk setiap kwh sebesar Rp. 450,-. Dengan demikian untuk mengolah 23,6 liter air limbah diperlukan 
biaya Rp.45,-., atau per meter kubik air limbah memerlukan biaya listrik Rp.1.900,-.

Biaya lain yang diperlukan adalah biaya hidrogen peroksida yaitu sekitar Rp.7000,- per liter. Untuk setiap liter air limbah memerlukan $0,25 \mathrm{ml}$ hidrogen peroksida atau $250 \mathrm{ml}$ setiap meter kubik air limbah atau Rp1.750,- per meter kubik air limbah. Jadi biaya listrik dan biaya hidrogen peroksida yang diperlukan sebesar Rp.3.656,- per meter kubik air limbah. Untuk skala yang lebih besar yaitu skala pabrik, biaya ini diperkirakan akan dapat turun lebih rendah lagi.

\section{KESIMPULAN}

Teknologi AOPs merupakan teknologi yang dapat digunakan untuk menghilangkan warna air limbah secara cepat. Dari data uji coba pengolahan air limbah produksi batik Jababeka skala semi pilot 100 liter, diperoleh kesimpulan sebagai berikut:

- Semakin tinggi konsentrasi ozon yang digunakan, maka reaksi pengilangan warna dengan AOPs akan semakin cepat.

- Laju alir gas pembangkit ozon optimum untuk proses AOPs diketahui sebesar 3 liter per menit.

- Reaksi penurunan warna dengan AOPs dapat diilustrasikan sebagai reaksi kimia orde 1 dengan konstanta kecepatan reaksi sebesar 0,38 per jam. Konstanta kecepatan reaksi dan orde reaksi ini dapat digunakan untuk mendisain reaktor AOPs skala plant.

- Biaya yang diperlukan untuk penghilangan warna air limbah mencakup biaya listrik dan biaya bahan kimia hidrogen peroksida yang besarnya Rp. 3.656,- per meter kubik air limbah.

\section{DAFTAR PUSTAKA}

1. Degreemont (1991),"Water Treatment Handbook, sixth edition.

2. Gottschalk, C., Libra, J. A.,Saupe, A.,2000," Ozonation of Water and Wastewater. A Practical Guide to Understanding Ozone and Its Application. Weinheim, German. WilleyVch Verlag Gmbh.

3. Langlais, B., D.A. Rechkov, D.R. Brink, 1991, "Ozon in Water Treatment, Application in Engineering", Lewis Publisher and AWWA Research Foundation, USA.

4. EPA, 1999 "Wastewater Technology Fact Sheet Ozon Desinfection", United States Environmental Protection Agency, Washington DC.
5. Mc.Calf and Eddy, 1978 "Wastewater Engineering", Mc Graw Hill.

6. Perkowski, J., Stainslaw L.,2002, " Decomposition of Anthraquinone Dye in the Aqueous Solution by Ozon, Hydrogen Peroxide or UV", Dept of Bioprocess Engineering, Institute of Radiation Chemistry, Poland.

7. Rudi N dan Ikbal.,Pengolahan Air Limbah Berwarna dengan AOPs", Journal Air Indonesia, vol 1 no 1.

8. Namboodri, C.G., W.W. Perkins, W.K.Walsh,1994 "Decolorizing Dyes With Chlorine And Ozon Part Il", Text. Engr. Dept., Auburn Univ.,Auburn, Alabama.

9. Karimi, A.A., J.A. Redman, W.H. Glaze, 1997, "Technology Overview", Journal AWWA.

10. Kementerian Lingkungan Hidup dengan ITB,2003 "Studi Penyusunan Baku Mutu Air Limbah Untuk Kegiatan Industri Dyestuff (Zat Warna) dan Industri Copper Smelter,

11. Octave Levenspiel, 1972 "Chemical Reaction Engineering, John Willey and Sons, Inc. $2^{\text {rd }}$. ed. 